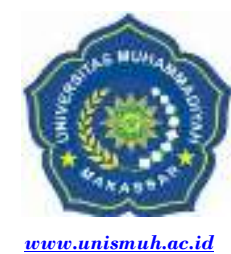

\title{
Eksistensi Nilai Sosial Budaya A'dengkapada dalam Acara Perkawinan Masyarakat Kelara Kabupaten Jeneponto
}

\author{
Hidayah Quraisy ${ }^{1)} \&$ Sitti Asnaeni ${ }^{2)}$ \\ Program Studi Pendidikan Sosiologi FKIP Universitas Muhammadiyah Makassar ${ }^{1)}$ \\ Program Studi Pendidikan Sosiologi FKIP Universitas Muhammadiyah Makassar ${ }^{2)}$ \\ hidayahquraisy@unismuh.ac.id ${ }^{1)}$ \& sittiasnaeni@unismuh.ac.id ${ }^{21}$
}

\begin{abstract}
Research on the existence of socio-cultural value a'dengkapada in the marriage event Kelara people Jeneponto Regency. This study aims to determine the existence and cultural values a'dengkapada in the marriage. The type of this research is descriptive qualitative method, data collection is used by observation, in-depth interview, documentation technique from result of photo and archives of local government. The results showed that, the existence of A'dengkap culture in marriage event still survive until now in Kelara society of Jeneponto Regency. The social values contained in the A'dengkapada culture are (1) As a tradition passed down from generation to generation, (2) Gratitude to the creator after the rice harvest and as a plea to be given safety in marriage and appeal (3) Entertainment for families and relatives in the afternoon (4) distant family gatherings (5) containers improve mutual cooperation and togetherness among families and relatives before carrying out the A'dengkapada event.
\end{abstract}

Keywords: Existence, Social Value, Culture, A'dengkapada

\begin{abstract}
Abstrak. Penelitian tentang eksistensi nilai sosial budaya a'dengkapada dalam acara perkawinan masyarakat Kelara Kabupaten Jeneponto. Penelitian ini bertujuan untuk mengetahui eksistensi dan nilai budaya $a^{\prime}$ dengkapada dalam acara perkawinan. Jenis penelitian ini adalah metode kualitatif deskriptif, pengumpulan data digunakan dengan cara observasi, wawancara mendalam, teknik dokumentasi dari hasil foto dan arsip pemerintah setempat. Hasil penelitian menunjukkan bahwa, eksistensi budaya $A^{\prime}$ dengkapada dalam acara perkawinan masih tetap bertahan hingga sekarang di masyarakat Kelara Kabupaten Jeneponto. Nilai-nilai sosial yang terkandung dalam budaya $A^{\prime}$ dengkapada yaitu (1) Sebagai adat istiadat yang turun temurun dari generasi ke generasi, (2) Rasa syukur kepada sang pencipta setelah panen padi dan sebagai permohonan agar diberi keselamatan dalam melangsungkan acara perkawinan serta permohonan agar diberi hasil tani yang lebih baik, (3) Hiburan bagi keluarga dan kerabat pada sore hari (4) wadah silaturahmi antar keluarga yang jauh (5) wadah meningkatkan rasa gotong royong dan kebersamaan antar keluarga dan kerabat sebelum melaksanakan acara $A^{\prime}$ dengkapada.
\end{abstract}

Kata Kunci : Eksistensi, Nilai Sosial, Budaya, A'dengkapada 


\section{PENDAHULUAN}

Masyarakat Indonesia adalah masyarakat majemuk (serba ganda). Kepulauan Indonesia terdiri atas 13.000 pulau besar maupun kecil, dan dihuni oleh 316 suku bangsa yang menggunakan lebih kurang 250 bahasa daerah. Tiap suku memiliki kebudayaan sendiri. Kebudayaan suku-suku bangsa Indonesia berbeda satu dengan yang lain. Bahasa, adat istiadat, bentuk rumah, pakaian dan kesenian tiap daerah/suku memiliki ciri khas yang berbeda dengan suku yang lain. Hal ini disebabkan karena kepulauan nusantara terdiri atas aneka warna kebudayaan yang secara umum dapat dideskripsikan dalam tiga aspek, yaitu: struktur kesukuan, distribusi wilayah agama dan dari aspek tingkat pendidikan. Namun keberagaman tersebut dalam konteks kekayaan menjadi kekayaan yang patut kita syukuri. Keberagaman dalam konteks nusantara menjadi konsep integrasi nasional dengan rumusan Bhineka Tunggal lka yang artinya Bhina = pecah, Ika = itu, Tunggal = satu, sehingga Bhineka Tunggal Ika artinya "terpecah itu satu". Keanekaragaman Indonesia dapat dilihat dalam perbedaan suku, adat istiadat, dialek bahasa daerah, kesenian, agama, namun secara keseluruhan keberagaman budaya tersebut terpadu dalam satu kesamaan lingkungan hukum adat dan budaya Nusantara. Keanekaragaman inilah yang menjadi pembeda suatu kelompok etnik dengan kelompok etnik yang lain. Kebudayaan dan atribut sosial budaya tersebut sebagai penanda identitas kelompok etnik yang memiliki sifat stabil, konsisten, dan bertahan lama.

E.B Tylor, (dalam Soerjono Soekanto, (2010: 150) mengemukakan bahwa; "kebudayaan adalah kompleks yang mencakup pengetahuan, kepercayaan, kesenian, moral, hukum, adat istiadat, dan lain kemampuan-kemampuan serta kebiasaan-kebiasaan yang didapatkan oleh manusia sebagai anggota masyarakat.

Masyarakat adalah orang yang hidup bersama yang menghasilkan kebudayaan. Sehingga tak ada masyarakat yang tidak mempunyai kebudayaan dan sebaliknya tak ada kebudayaan tanpa masyarakat sebagai wadah pendukungnya. Karena kebudayaan merupakan hasil dari masyarakat yang sudah turun temurun dari generasi ke generasi, maka masyarakat harus mampu menjaga nilai-nilai dan mempertahankan keberadaan atau eksistensi budayanya.

Eksistensi atau keberadaan suatu budaya dalam suatu daerah merupakan salah satu ciri khas daerah tersebut. Karena pada hakikatnya setiap daerah memiliki budaya yang berbeda dengan daerah yang lain. Misalnya saja kebudayaan yang terdapat di Sulawesi Selatan.

Pada masyarakat Sulawesi Selatan terdapat banyak kebudayaan yang berbeda dengan daerah lain yang terdapat di Sulawesi Selatan. Karena penduduk Sulawesi Selatan terdiri atas empat suku, yaitu Bugis, Makassar, Toraja, Mandar. Suku bugis mendiami kabupaten Sinjai, Bulukumba, Bone, Soppeng, Wajo, Sidenreng Rappang, Pinrang, Enrekang, Luwu, Pare-pare, Barru, Pangkajene dan Maros. Sedangkan Suku Makassar mendiami beberapa kabupaten, yaitu Gowa, Takalar, Jeneponto, Bantaeng, Maros dan Pangkajene.

Pada masyarakat Jeneponto khususnya di Kecamatan Kelara terdapat budaya yang sering dilakukan oleh masyarakat yaitu A'dengka Pada yang dalam bahasa Indonesia artinya menumbuk secara bersama. A'dengka Pada juga diartikan sebagai budaya tumbuk lesung.

Pada dasarnya masih banyak masyarakat yang belum mengetahui Keberadaan budaya A'dengka Pada di Jeneponto. Padahal budaya A'dengka Pada sudah lama dilakukan oleh masyarakat Jeneponto khususnya di Kecamatan Kelara.

Hal ini mungkin diakibatkan oleh karena tidak semua masyarakat Jeneponto yang melakukan Budaya A'dengka Pada, hanya keluarga-keluarga yang mempunyai garis keturunan dari nenek moyangnya yang dulu sering melakukan budaya A'dengka Pada pada saat akan menggelar acara perkawinan yang masih melakukannya sampai sekarang.

Masyarakat Kelara tetap melaksanakan budaya A'dengka Pada karena masyarakat memegang teguh nilai-nilai positif yang tertanam dalam budaya tersebut. Nilai-nilai positif yang terkandung dalam budaya A'dengka Pada adalah 
sebagai adat istiadat masyarakat Kelara yang sudah turun temurun dan masih bertahan dan dilakukan hingga sekarang. Selain itu, A'dengka Pada juga sebagai salah satu ungkapan rasa syukur kepada sang pencipta atas rezeki yang didapatkan setelah panen, dan juga sebagai hiburan yang disuguhkan kepada masyarakat setempat. Selain itu, budaya A'dengka Pada juga merupakan salah satu ajang silaturahmi antar keluarga dan kerabat yang jauh. Dalam melakukan budaya A'dengka Pada masyarakat akan saling bergotong royong dalam mempersiapkan semua alat dan bahan yang dibutuhkan dalam A'dengka Pada. Namun dalam melakukan budaya A'dengka Pada seringkali terjadi persaingan antar keluarga yang melakukan budaya A'dengka Pada, misalnya keluarga yang satu lebih ramai maka keluarga yang lain pun akan berusaha menyaingi dan berusaha lebih ramai dibandingkan keluarga yang lain.

Budaya A'dengka Pada harus tetap dilakukan oleh masyarakat Kelara agar budaya seperti ini tetap lestari dan bisa dinikmati oleh kalangan anak muda dan agar budaya A'dengka Pada ini bisa diperkenalkan kepada dunia luar khususnya yang belum mengetahui keberadaan budaya $A^{\prime}$ dengka Pada yang biasa dilakukan oleh masyarakat Kelara pada saat akan menggelar acara perkawinan. Budaya A'dengka Pada sebenarnya hampir sama dengan budaya tumbuk lesung di daerah lain, namun yang membedakannya ialah pada masyarakat Kelara mereka melakukan budaya $A^{\prime}$ dengka Pada atau tumbuk lesung pada saat akan menggelar acara perkawinan sementara di daerah lain mereka melakukan budaya tumbuk lesung pada saat akan menggelar acara pesta panen.

\section{METODE PENELITIAN}

Jenis penelitian yang digunakan dalam penelitian mengenai eksistensi nilai sosial budaya A'dengka pada dalam acara perkawinan masyarakat kelara kabupaten jeneponto adalah penelitian kualitatif. Teknik pengambilan sampel yang digunakan dalam penelitian ini secara purposive sampling. Dimana purposive sampling adalah dengan memilih secara langsung informan atau responden berdasarkan kriteria atau yang diperkirakan dapat menjawab atau memberikan informasi mengenai apa yang dibutuhkan peneliti. Kategori informan yang digunakan dalam penelitian ini yaitu informan kunci, informan utama, dan informan tambahan. Jenis dan sumber data penelitian bersumber data primer dan data sekunder, yang didapatkan melalui teknik pengumpulan data observasi langsung, wawancara (interview), dokumentasi. Teknik analisis data dilakukan dengan analisis data kualitatif deskriptif untuk menginterpretasikan hasil penelitian, baik yang melalui observasi langsung ataupun wawancara mendalam. Data penelitian kualitatif tidak berbentuk angka, tetapi lebih banyak berupa narasi, deskripsi, cerita, dokumen tertulis dan tidak tertulis (gambar,foto) ataupun bentuk-bentuk non angka lainnya, melalui tahapan pengumpulan data, eksplorasi data atau informasi, menganalisis data dan menyimpulkan data. Penelitian ini menggunakan triangulasi sumber, triangulasi teknik pengumpulan data, dan triangulasi waktu sebagai keabsahan data.

\section{PEMBAHASAN}

\section{Eksistensi Budaya A'dengka Pada dalam Acara Perkawinan}

Eksistensi menurut kamus besar bahasa Indonesia artinya keberadaan, kehadiran yang mengandung unsur bertahan. Berkaitan dengan budaya A'dengka Pada berarti keberadaan budaya A'dengka Pada dalam masyarakat yang turun temurun dan masih bertahan hingga sekarang.

Dahulu yang pertama kali melakukan budaya A'dengka Pada ialah kaum karaeng dan orangorang yang mempunyai keturunan atau leluhurnya yang melakukan budaya A'dengka Pada, yang mereka tumbuk ialah sembilan ikat padi. Dan hal itu merupakan kebiasaan mereka yang masih terus berlangsung hingga sekarang. Hal tersebut di atas berkaitan dengan pemikiran George Herbert Mead tentang interaksi simbolik yang menurutnya dirangkum oleh tiga konsep yaitu pikiran, diri, dan masyarakat. Pikiran merupakan interaksi simbolik dengan diri yang terjadi melalui suatu proses yang terjadi dalam masyarakat. Hubungan terjadi secara alami antara manusia dalam masyarakat dan 
hubungan masyarakat dengan individu. Interaksi yang terjadi antar individu berkembang melalui simbol-simbol yang mereka ciptakan. Dalam acara A'dengka Pada simbol yang selalu ada adalah padi sebagai simbol utama dalam A'dengka Pada. Padi merupakan simbol yang memiliki makna bahwa semakin tinggi kedudukan seseorang maka seseorang itu harus semakin menunduk, dan juga padi dilambangkan sebagai ungkapan rasa syukur kepada sang pencipta atas keberhasilan panen dan juga sebagai permohonan agar dimasa kedepannya dapat memperoleh hasil yang lebih baik. Itulah mengapa padi merupakan komponen yang harus selalu ada dalam A'dengka Pada.

Masyarakat Kelara masih tetap melakukan dan mempertahankan keberadaan budaya A'dengka Pada hingga kini ialah agar budaya ini tetap bertahan dan bisa dinikmati oleh kalangan anak muda, walaupun banyak perubahan yang terjadi dalam masyarakat yang mengakibatkan pudar atau bahkan hilangnya suatu budaya, maka masyarakat harus mempertahankan budayanya karena suatu budaya akan tetap bertahan apabila pelaku budaya atau masyarakat tetap mempertahankan eksistensi kebudayaan mereka, dan tidak terpengaruh oleh globalisasi.

\section{Nilai Sosial yang Terkandung dalam Budaya A'dengka Pada}

Menurut Horton dan Hunt (dalam J. Dwi Narwoko dan Bagong Suyanto, (2011: 55), mengemukakan bahwa; "nilai adalah gagasan mengenai apakah suatu pengalaman itu berarti atau tidak berarti. Nilai pada hakikatnya mengarahkan perilaku dan pertimbangan seseorang, tetapi ia tidak menghakimi apakah sebuah perilaku tertentu itu salah atau benar. Nilai itu lebih dari sekedar keyakinan, nilai selalu menyangkut perbuatan atau tindakan. Nilai menjadikan manusia terdorong untuk melakukan tindakan. A'dengka Pada merupakan suatu tindakan budaya yang dilakukan oleh masyarakat dan masyarakat sebagai pelaku budaya menerima segala nilai-nilai sosial budaya yang terkandung dalam kebudayaan tersebut Dalam budaya A'dengka Pada terkandung nilai-nilai sosial yang bersifat positif dan negatif. Nilai-nilai sosial yang bersifat positif dan negatif yang terkandung dalam budaya $A^{\prime}$ dengka Pada adalah sebagai berikut:

a. Sebagai adat istiadat masyarakat Kelara yang sudah turun temurun dari generasi ke generasi. A'dengka Pada memang merupakan suatu adat istiadat masyarakat yang turun termurun dari generasi ke generasi. Hal ini terlihat dari eksistensi atau keberadaan budaya $A^{\prime}$ dengka Pada yang masih bertahan hingga sekarang dan masih terus dilakukan oleh masyarakat Kelara. A'dengka Pada sebagai adat istiadat harus tetap dijaga, dilakukan, dan dipelihara oleh generasi tua agar budaya A'dengka Pada tersebut bisa tetap dinikmati oleh generasi muda masa kini dan generasi muda yang akan datang.

b. Sebagai ungkapan rasa syukur kepada sang pencipta. Masyarakat melakukan A'dengka Pada sebagai ungkapan rasa syukur mereka kepada sang maha kuasa. A'dengka Pada merupakan salah satu tradisi masyarakat Kelara Kabupaten Jeneponto yang terus dipelihara dan dilakukan oleh masyarakat setempat. A'dengka Pada dilakukan pada saat menggelar acara perkawinan. Masyarakat Kelara mengatakan bahwa A'dengka Pada ini sebagai ungkapan rasa syukurnya kepada sang pencipta setelah panen padi. Karena biasanya setelah panen padi masyarakat banyak yang menggelar acara perkawinan, sehingga dalam acara perkawinan itulah kemudian masyarakat mengungkapkan rasa syukurnya karna mereka mampu menggelar sebuah acara. Dalam A'dengka Pada masyarakat menggunakan padi sebagai salah satu komponen yang ditumbuk saat $A^{\prime}$ dengka Pada. Masyarakat memilih padi karena padi merupakan salah satu makanan pokok masyarakat Kelara.

c. Sebagai hiburan. A'dengka Pada merupakan salah satu hiburan yang disuguhkan kepada keluarga dan kerabat pada sore hari selama tiga hari berturut-turut. Dalam acara A'dengka Pada para gadis-gadis akan berdandan secantik mungkin dan memakai pakaian baju bodo. Mereka memakai baju bodo karena baju bodo merupakan pakaian khas suku makassar. Salah 
satu yang membuat menarik dalam $A^{\prime}$ dengka Pada para gadis-gadis akan melakukan gerakan assoe (mengayungkan tangan kebelakang). Dalam gerakan itu gadis-gadis memperlihatkan keluwesan tangan mereka dalam melakukan gerakan assoe (mengayungkan tangan kebelakang), dan ini menjadi salah satu hiburan tersendiri yang disuguhkan kepada masyarakat ataupu kerabat pada yang datang pada sore hari.

d. Sebagai ajang silaturahim antar keluarga ataupun kerabat. Acara A'dengka Pada semua keluarga dan kerabat dekat saling berkumpul untuk melaksanakan ataupun untuk menyaksikan acara A'dengka Pada. Biasanya kerabat atau keluarga yang sudah lama tidak bertemu akan bertemu pada saat dilakukannya acara A'dengka Pada. Sehingga ini menjadi sebagai salah satu tempat untuk saling memupuk silaturahim antar keluarga dan kerabat. Silaturahim ini merupakan salah satu nilai positif yang terkandung budaya $A^{\prime}$ dengka pada yang harus tetap dipertahankan oleh masyarakat.

e. Meningkatkan rasa kebersamaan dan gotong royong. A'dengka Pada merupakan salah satu cara untuk memupuk rasa kebersamaan dan gotong royong antar masyarakat Kelara, sebelum acara A'dengka Pada dimulai, keluarga dan para kerabat dekat akan saling bergotong royong menyiapkan lesung panjang, tiga batang alat penumbuk misalnya bambu ataupun kayu keras, serta memanggil gadis-gadis muda untuk A'dengka Pada. Gotong rotong sangat terlihat sebelum acara A'dengka Pada dimulai karena terlebih dahulu masing-masing menyiapkan peralatan dan bahan-bahan yang akan digunakan saat $A^{\prime}$ dengka Pada. Sikap gotong royong merupakan salah satu budaya dan ciri masyarakat Kelara.

Namun dibalik adanya rasa gotong royong dan kebersamaan, seringkali dalam A'dengka Pada menyebabkan adanya rasa persaingan antar keluarga yang $A^{\prime}$ dengka Pada, misalnya keluarga yang satu lebih ramai dibandingkan dengan keluarga yang lain. Akan tetapi masyarakat Kelara tetap menjujung tinggi rasa gotong royong, karena menurut mereka gotong royong merupakan suatu konsep yang erat sangkut pautnya dengan kehidupan masyarakat Indonesia pada umumnya dan masyarakat Kelara pada khususnya sebagai masyarakat agraris, oleh karena itu gotong royong bagi masyarakat Kelara sangat bernilai tinggi.

Nilai gotong royong merupakan latar belakang dari segala aktivitas tolong menolong antar masyarakat. Aktivitas tersebut tampak dalam antar tetangga, antar kerabat dan terjadi secara spontan tanpa ada permintaan atau pamrih bila ada sesama yang sedang kesusahan. Dalam sistem nilai budaya Indonesia, gotong royong mengandung 4 konsep : Pertama, manusia tidak hidup sendiri di dunia ini, tetapi dikelilingi oleh komunitasnya, masyarakatnya, dan alam semesta sekitarnya. Kedua, dalam segala aspek kehidupan manusia pada hakekatnya tergantung terhadap sesamanya. Ketiga, memelihara hubungan baik dengan sesamanya, terdorong oleh jiwa sama-rata samarasa. Keempat, selalu berusaha untuk sedapat mungkin bersifat konform, berbuat sama dan bersama dengan sesamanya.

Seluruh konsep tersebut memberikan sifat ketergantungan kepada sesama, dimana hal tersebut menciptakan satu rasa keamanan nurani yang sangat dalam. Gotong royong merupakan kunci budaya kontemporer Indonesia, yang menggambarkan masyarakat didalamnya dan semua kebijakan yang diambil dalam kehidupan bermasyarakat harus berdasarkan konsep gotong royong. Sikap gotong royong dan rasa kebersamaan masyarakat terlihat dari sebelum acara $A^{\prime}$ dengka Pada dimulai masyarakat sekitar akan saling bergotong royong mempersiapkan semua alat dan bahan yang akan digunakan dalam acara $A^{\prime}$ dengka Pada.

Hal tersebut di atas sejalan dengan pemikiran Waters (dalam I.B. Wirawan 2012: 134), yang mengemukakan konsep verstehen lebih mengarah pada suatu tindakan bermotif pada tujuan yang hendak dicapai atau in order to motive. Pemikiran Waters ini sejalan dengan budaya masyarakat yang saling bergotong royong dalam acara $A^{\prime}$ dengka 
Pada. Masyarakat saling bergotong royong karena sama-sama memiliki tujuan yang hendak dicapai.

\section{KESIMPULAN}

Eksistensi atau keberadaan budaya $A^{\prime}$ dengka Pada dalam acara perkawinan masih tetap bertahan dan masih dilakukan hingga sekarang khususya pada masyarakat Kelara Kabupaten Jeneponto. Budaya A'dengka Pada sudah sejak lama dilakukan oleh masyarakat Kelara Kabupaten Jeneponto dan sudah turun temurun dari generasi ke generasi dan masih bertahan hingga sekarang.

Nilai-nilai sosial budaya yang terkandung dalam budaya $A^{\prime}$ dengka Pada ialah sebagai:

1. Adat istiadat masyarakat Kelara yang sudah turun temurun dalam masyarakat dari generasi ke generasi.

2. Ungkapan rasa syukur kepada sang pencipta atas keberhasilan masyarakat setelah panen padi. Hal ini dimaksudkan sebagai ungkapan syukur setelah panen dan sebagai permohonan agar dimasa kedepannya dapat memperoleh hasil tani yang lebih baik.

3. Menumbuhkan rasa kebersamaan dan gotong royong. Gotong royong masyarakat terlihat dari sebelum acara A'dengka Pada dimulai masyarakat bergotong royong menyiapkan segala peralatan yang akan digunakan dalam acara A'dengka Pada.

4. Sebagai hiburan yang disuguhkan kepada keluarga dan kerabat pada sore hari selama tiga hari berturut-turut.

5. Silaturahmi, A'dengka Pada sebagai ajang silaturahmi antar keluarga yang berjauhan.

6. Persaingan antar keluarga yang $A^{\prime}$ dengka Pada, apabila keluarga yang $A^{\prime}$ dengka Pada lebih ramai.

\section{DAFTAR PUSTAKA}

[1] Ahmadi, Abu. (2007). Sosiologi Pendidikan. Jakarta: PT. Rineka Cipta.

[2] Anshary MK, M. (2010). Hukum Perkawinan Di Indonesia. Yogyakarta: Pustaka Pelajar

[3] Eoh, O.S. (2001). Perkawinan Antar Agama Dalam Teori Dan Praktek. Jakarta: PT. Raja Grafindo.

[4] Garna, K. Judistira. (1996). IImu-IImu Sosial DasarKonsep-Posisi. Bandung: Program Pascasarjana Universitas Padjdjaran.
[5] Herimanto dan Winarno. (2013). Ilmu Sosial Dan Budaya Dasar. Jakarta: Bumi Aksara.

[6] Narwoko, J. Dwi. (2011). Sosiologi Teks dan Terapan. Jakarta: Kencana.

[7] Nasution, S. (2003). Metode Research ( Penelitian Ilmiah ). Jakarta: PT. Bumi Aksara.

[8] Shadily, Hassan. (1999). Sosiologi Untuk Masyarakat Indonesia. Jakarta: PT. Rineka Cipta.

[9] Soekanto, Soerjono. (2010). Sosiologi Suatu Pengantar. Jakarta: Rajawali Pers.

[10] Tahir, Muh. (2013). Metodologi Penelitian. FKIP. Universitas Muhammadiyah Makassar.

[11] Tim Kreatif ( Ed.). (2010). Sosiologi Tuntunan Ke Universitas. Jakarta: Graha Pustaka Jakarta.

[12] Tim Penyusun FKIP Unismuh. (2013). Pedoman Penulisan Skripsi. Makassar: Panrita Press Unismuh Makassar

[13] Tumanggor, Rusmin dan Kholis Ridho. (2010). Ilmu Sosial dan Budaya Dasar. Jakarta: Kencana.

[14] Wahyu, Ramdani. (2012). Ilmu Budaya Dasar. Bandung: CV. Pustaka Setia.

[15] Wirawan, I.B (2011). Teori-Teori Sosial Dalam Tiga Paradigma (Fakta Sosial, Definisi Sosial, Dan Pelaku Sosial). Surabaya: PT Kharisma Utama.

[16] April's Blog. (2012). Perbedaan Serta Persamaan Tradisi dan Kebudayaan (Online), (http: aprilliamanansal.blogspot.com, diakses 22 Mei 2015).

[17] Bloginfo. (2013). Definisi Perkawinan Menurut Hukum Islam (Online), (http: bloginfo.heck.in/definisi-perkawinan-hukumislam, diakses 03 September 2015).

[18] Maftuh Kholil. (2008). Bid'ah, Budaya (tradisi), dan Sunnah (Online), (https:// Suara al ikhwan.wordpress.com, diakses 22 Mei 2015).

[19] Muhlis, Ade. (2013). Upacara Seren Taun Adat Sunda Budaya Indonesia (Online), (http:// www.Budayaindonesia.net,/upacara-seren-taunsunda, diakses 23 Mei 2015).

[20] Norhidayah, Fauza. (2013). Konsep Teori Eksistensialisme (Online), (http:/ /Kompasiana, diakses 25 Januari 2015).

[21] Nur Chaerani. (2012). Mappadendang (Online), (http:// Nur Chaerani. blogspot.com. Budaya Suku Bugis, diakses 25 Januari 2015)

[22] Turwanto, Tewe. (2013). Budaya Nusantara Sulawesi Selatan (Kebudayaan Bugis, Kebudayaan Makassar, Kebudayaan Mandar, Kebudayaan Toraja) (Online). (https://Prezi.com Budayanusantara, diakses 22 Mei 2015). 